\title{
Article
}

\section{Leaching of Cs and Sr from Sewage Sludge Ash Buried in a Landfill Site}

\author{
Nao ISHIKAWA ${ }^{1, *}$, Ayumi ITO ${ }^{2}$ and Teruyuki UMITA ${ }^{1}$ \\ ${ }^{1}$ Department of Civil and Environmental Engineering, Iwate University, 4-3-5 Ueda, Morioka-shi, Iwate 020-8551, Japan \\ ${ }^{2}$ Department of Frontier Materials and Function Engineering, Graduate School of Engineering, Iwate University, \\ 4-3-5 Ueda, Morioka-shi, Iwate 020-8551, Japan
}

\begin{abstract}
Radionuclide contamination from the nuclear accident at the Fukushima Daiichi Nuclear Power Plant has been found in sewage sludge ash produced in eastern Japan. When such contaminated waste contains less than $8,000 \mathrm{~Bq} / \mathrm{kg}$ radiocesium, it is being disposed in controlled landfill sites. In order to assess the possible spread of the radionuclides by their leaching from the landfill sites, it is important to know the leaching behavior of the radionuclides from the sewage sludge ash and factors influencing the leaching behavior. In this study, leaching experiments using stable $\mathrm{Cs}$ and $\mathrm{Sr}$ were conducted for sewage sludge ash under several conditions to investigate effects of chemical composition of leachate, $\mathrm{pH}$, and solid/liquid ratio on $\mathrm{Cs}$ and $\mathrm{Sr}$ leaching behaviors. In the $\mathrm{pH}$ range from 6 to 12, the leaching ratio of Cs or Sr was less than 5.2 or $0.21 \%$, respectively. Additionally, the leaching ratio of $\mathrm{Sr}$ decreased with increasing $\mathrm{pH}$ of the leachate. In contrast, the higher the $\mathrm{pH}$ in the leachate was, the higher the leaching ratio of Cs was. Finally, possible radionuclide leaching from contaminated sewage sludge ash and then radionuclide concentrations in an actual landfill leachate were assessed. It could be suggested that ${ }^{90} \mathrm{Sr}$ leaching from the landfill site had the least effect on the environment, whereas ${ }^{134+137} \mathrm{Cs}$ leaching needed to be taken into account for spreading radioactive materials from the landfill site to the environment.
\end{abstract}

KEYWORDS: cesium, strontium, sewage sludge ash, leaching, landfill site, $p H$

\section{Introduction}

Radioactive materials were released into the environment during the Fukushima Daiichi Nuclear Power Plant Accident in 2011, and they migrated via various pathways such as water bodies, soil, and living organisms ${ }^{1-4)}$. Therefore, many places are currently suffering contamination problems. It has been reported that radioactive materials flowed into sewers and migrated into sewage sludge which was then converted to sewage sludge ash and condensed ${ }^{5}$, and periodic measurements of radioactive cesium $\left({ }^{134} \mathrm{Cs}\right.$ and $\left.{ }^{137} \mathrm{Cs}\right)$ concentrations in sewage sludge ${ }^{6}$ confirm this occurrence. However, concentrations differ depending on the area and the sewage system involved, and maximum concentrations have been reported as $446,000 \mathrm{~Bq} / \mathrm{kg}$ in Fukushima Prefecture, $1,430 \mathrm{~Bq} / \mathrm{kg}$ in Miyagi Prefecture, and

\footnotetext{
* Corresponding author, E-mail: naoki@iwate-u.ac.jp

DOI : 10.15669 /fukushimainsights. Vol.4.244

(C) 2021 Atomic Energy Society of Japan. All rights reserved.

Originally published in Transactions of the Atomic Energy Society of Japan (ISSN 1347-2879), Vol. 13, No. 3, p.87-93

(2014) in Japanese. (Japanese version accepted: April 14, 2014)
} 
$2,510 \mathrm{~Bq} / \mathrm{kg}$ in Iwate Prefecture ${ }^{7)}$. The government permits the disposal of sewage sludge and sewage sludge ash (after appropriate treatment) with radioactive Cs concentrations under $8,000 \mathrm{~Bq} / \mathrm{kg}$ in existing controlled landfill sites ${ }^{8}$, and landfill disposal of sewage sludge ash containing under $8,000 \mathrm{~Bq} / \mathrm{kg}$ is occurring in accordance with this stipulation.

Leachate water is generated from controlled final disposal sites after rainwater infiltrates and passes through the waste (sludge ash, glasses, ceramics and concrete rubbish) and landfill deposited therein. Radioactivity has been reported in rainwater leachate from waste sites ${ }^{9}$. It is known that the leachate from sewage sludge ash contains much less radioactive Cs than that from general refuse incineration ash ${ }^{10,11)}$. However, the leachate characteristics depend on the type of waste disposed of in the landfill site, and are also related to $\mathrm{pH}$ conditions, which generally range from neutral to alkaline, with high concentrations of salts with cations such as $\mathrm{Ca}^{12-14)}$. To date, there have been no reports on the leachate properties of radioactive materials from sewage sludge ash with respect to alkaline or high salt concentration solutions. This study therefore aims to clarify the $\mathrm{pH}$ dependence (in a range of neutral to alkaline) of the solute content of leachate from sewage sludge ash generated in Iwate Prefecture and to determine the influence of the leachate salt type and solid/liquid ratio during leaching.

The radioactive materials of concern are radioactive $\mathrm{Cs}\left({ }^{134} \mathrm{Cs}\right.$ and $\left.{ }^{137} \mathrm{Cs}\right)$ and radioactive $\mathrm{Sr}$

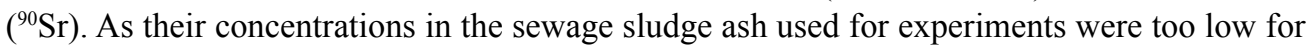
use in conducting direct measurements, their leaching properties were estimated by determining the leaching properties of stable isotopes ${ }^{133} \mathrm{Cs}$ and ${ }^{88} \mathrm{Sr}$.

\section{Experimental Methodology}

\section{Sampling Collection and Method of Analysis}

This study used samples of sewage sludge ash from the Tonan Purification Center in Morioka Iwate Prefecture. The concentrations of Fe, P, and Si in the sewage sludge ash were measured using a sequential X-ray fluorescence spectrometer (Shimadzu, XRF-1800). For other elements, the concentrations of $\mathrm{Cs}$ and $\mathrm{Rb}$ were measured using inductively coupled plasma mass spectrometry (ICP-MS, Thermo, iCAP Qs), and the concentrations of $\mathrm{Al}, \mathrm{Ca}, \mathrm{K}, \mathrm{Mg}, \mathrm{Mn}$, and $\mathrm{Sr}$ were measured using inductively coupled plasma atomic emission spectrometry (ICPAES, Shimadzu, ICPE9000) after decomposing each sample in accordance with the boiling and elution method and using nitric acid and hydrochloric acid in the sewage testing method ${ }^{15}$. The concentrations of elements within the sewage sludge ash are shown in Table 1, where it is evident that the content of $\mathrm{Al}, \mathrm{Ca}, \mathrm{P}$, and $\mathrm{Si}$ was high.

\section{Leaching Experiment}

(1) Experiment to determine leaching equilibrium time

The batch leaching experiment involved conducting the following experiments to determine the time until equilibration was reached in the leaching of Cs and $\mathrm{Sr}$ from sewage sludge ash.

A mixture of $3 \mathrm{~g}$ of sewage sludge ash and $30 \mathrm{~mL}$ of leachate was prepared in a $50-\mathrm{mL}$ polyethylene bottle, then shaken at 25 degrees $\mathrm{C}$ and $120 \mathrm{rpm}$. Ultrapure water, $10^{-4} \mathrm{~mol} / \mathrm{L} \mathrm{NaOH}$ solution, and $10^{-2} \mathrm{~mol} / \mathrm{L} \mathrm{Ca}(\mathrm{OH})_{2}$ solution were used as leaching liquids. After shaking, the samples were collected at various intervals ranging from 30 minutes to 96 hours. The samples were then filtered through a $0.45 \mu \mathrm{m}$ membrane filter, element concentrations in the filtrate 
Table 1 Element concentrations leaching from ash

\begin{tabular}{|c|c|c|c|}
\hline & {$[\mathrm{mg} / \mathrm{kg}$} & & {$[\mathrm{g} / \mathrm{kg}]$} \\
\hline Cs & 0.63 & $\mathrm{~A} 1$ & 39.7 \\
\hline \multirow[t]{8}{*}{$\mathrm{Rb}$} & 8.27 & $\mathrm{Ca}$ & 96.4 \\
\hline & & $\mathrm{Fe}$ & 33.3 \\
\hline & & K & 6.37 \\
\hline & & $\mathrm{Mg}$ & 28.4 \\
\hline & & $\mathrm{Mn}$ & 1.34 \\
\hline & & $\mathrm{P}$ & 89.5 \\
\hline & & $\mathrm{Si}$ & 74.0 \\
\hline & & $\mathrm{Sr}$ & 0.44 \\
\hline
\end{tabular}

were measured using ICP-MS and ICP-AES, and the leaching ratio was calculated using the following equation,

Leaching Ratio [\%]

$$
=\frac{\text { Amount of Element Leaching from Ash }[\mathrm{mg} / \mathrm{kg}]}{\text { Element Content in Ash used for Leaching Experiment }[\mathrm{mg} / \mathrm{kg}]} \times 100
$$

Also, the $\mathrm{pH}$ of the filtrate was measured using a $\mathrm{pH}$ meter (TOADKK, HM-25R).

\section{(2) Leaching experiment}

To clarify the leaching of $\mathrm{Cs}$ and $\mathrm{Sr}$ from sewage sludge ash, a batch leaching experiment was conducted. Three solution compositions, containing either $\mathrm{NaOH}, \mathrm{KOH}$, or $\mathrm{Ca}(\mathrm{OH})_{2}$ were used as the leaching liquids. The several initial molar concentrations (and $\mathrm{pH}$ ) of each were as follows. $\mathrm{NaOH}: 10^{-4}(6.7), 10^{-3}(9.0), 10^{-2}(11.5), 5 \times 10^{-2}(12.3)$ and $10^{-1}(12.6)$; $\mathrm{KOH}: 10^{-4}(6.6)$, $10^{-3}(8.0), 10^{-2}(11.4), 0.5 \times 10^{-1}(12.3)$, and $10^{-1}(12.6)$; and $\mathrm{Ca}(\mathrm{OH})_{2}: 10^{-5}(7.2), 10^{-4}(10.5)$, $10^{-3}(11.9)$, and $10^{-2}(12.9)$. An experiment using ultrapure water as the leaching liquid was also conducted.

A mixture of sewage sludge ash and leaching liquid (in a solid/liquid ratio of 0.1 ( $3 \mathrm{~g}$ : $30 \mathrm{~mL}$ )) was prepared in a $50 \mathrm{~mL}$ polyethylene bottle and then shaken by a shaker at 120 rpm and 25 degrees C. As leaching equilibration was reached within three days after shaking started (in accordance with information presented in Section III-1), the shaking duration was set at three days. After shaking, suction filtration of the sample was conducted using a $0.45-\mu \mathrm{m}$ membrane filter, the element concentration in the filtrate was measured using ICP-MS and ICP-AES, and the leaching ratio was acquired.

Also, the $\mathrm{pH}$ of the filtrate was measured using a $\mathrm{pH}$ meter (TOADKK, HM-25R).

Observations of the influence of the solid/liquid ratio on the leaching ratio were conducted using the $\mathrm{NaOH}$ solution and $\mathrm{KOH}$ solution at $10^{-2} \mathrm{~mol} / \mathrm{L}$ and five varied solid/liquid ratios of sewage sludge ash and leaching liquids in the range of 0.01 to $0.5(0.3 \mathrm{~g}: 30 \mathrm{~mL}, 1.5 \mathrm{~g}: 30 \mathrm{~mL}$, $3 \mathrm{~g}: 30 \mathrm{~mL}, 9 \mathrm{~g}: 30 \mathrm{~mL}, 15 \mathrm{~g}: 30 \mathrm{~mL}$ ). A similar experiment was conducted as described above and the leaching ratio was acquired. 


\section{Results and Discussions}

\section{Determination of Leaching Equilibration Time}

The leaching ratios of $\mathrm{Cs}$ and $\mathrm{Sr}$ in the sample with respect to the shaking duration are shown in Figure 1, where it is evident that a constant leaching ratio was reached in approximately three days. The $\mathrm{pH}$ fluctuations in the samples were determined as follows: for the $\mathrm{NaOH}$ solution, the initial $\mathrm{pH} 7.1$ stabilized at around 6.9 on the third day, and for the $\mathrm{Ca}(\mathrm{OH})_{2}$ solution, the initial pH 11.7 stabilized at around 8.6 within three days. From the above, it was considered that equilibration was reached after a shaking duration of three days.

The decrease in $\mathrm{pH}$ could be attributed to the dissolution of $\mathrm{Al}$ that existed in the sewage sludge ash, which caused the reaction $\mathrm{Al}^{3+}+4 \mathrm{OH}^{-} \rightarrow\left[\mathrm{Al}(\mathrm{OH})_{4}\right]^{-16)}$, or related to $\mathrm{OH}^{-}$consumption by the leaching of $\mathrm{AlPO}_{4}$ existing in the ash by the following reaction ${ }^{17}$,

$$
\mathrm{AlPO}_{4}+4 \mathrm{NaOH} \longrightarrow \mathrm{NaAlO}_{2}+\mathrm{Na}_{3} \mathrm{PO}_{4}+2 \mathrm{H}_{2} \mathrm{O}
$$

\section{Leaching Properties of Cs and Sr}

The leaching ratios of $\mathrm{Cs}$ at the $\mathrm{pH}$ of each leachate are shown in Figure 2, where it is evident that the leaching ratio is generally lower than $6 \%$ between $\mathrm{pH} 6$ and 12, showing that leaching is restricted. Leaching ratios were approximately $0.4 \%$ for all leachates in the neutral $\mathrm{pH}$ range, but $\mathrm{Cs}$ showed a higher leaching ratio tendency with increasing $\mathrm{pH}$. Furthermore,

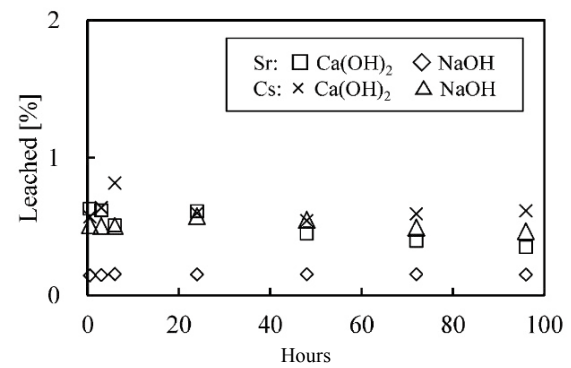

Figure 1 Effect of contact time on the leaching of $\mathrm{Cs}$ and $\mathrm{Sr}$

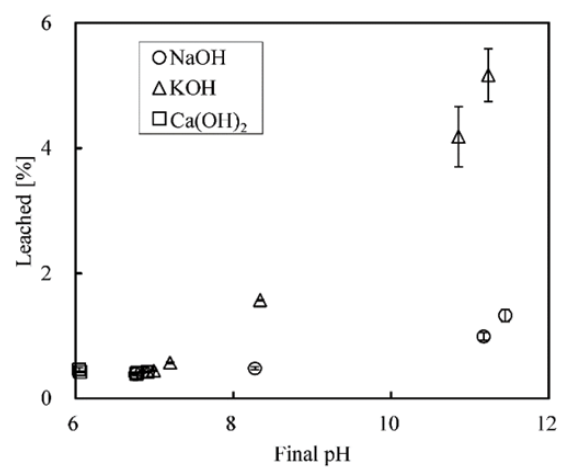

Figure $2 \mathrm{pH}$ dependence of leaching of $\mathrm{Cs}($ solid/liquid ratio $=0.1)$ 
a higher leaching ratio was seen when leached with $\mathrm{KOH}$ solution than with $\mathrm{NaOH}$ solution, even at the same $\mathrm{pH}$. This is because $\mathrm{K}$ has a behavior similar to $\mathrm{Cs}$, and the exchange reaction is occurred between Cs existing in the ash in a comparatively mobile form and $\mathrm{K}$ in the leachate, so that the leaching rate of $\mathrm{Cs}$ may be high if the $\mathrm{K}$ concentration is high. To determine the influence of $\mathrm{K}$ concentration on Cs leaching, the leaching ratio between $\mathrm{K}$ and $\mathrm{Cs}$ with $\mathrm{NaOH}$ was determined by subtraction from that with $\mathrm{KOH}$ at almost equal final $\mathrm{pHs}(\mathrm{pH} \mathrm{6.9,} \mathrm{8.3,}$ and 11.2). The value of $L_{\mathrm{KOH}-\mathrm{NaOH}}$ represents increments of the leaching ratio due to increases in the $\mathrm{K}$ concentration when the influence of $\mathrm{pH}$ is eliminated. Figure 3 shows fluctuations of the $L_{\mathrm{KOH}-\mathrm{NaOH}}$ value related to concentrations of $\mathrm{K}$. Linear regression shows that the rate of increase in the Cs leaching ratio relative to the increase in the $\mathrm{K}$ concentration can be estimated as $0.82 \%$ per $\mathrm{K}$ concentration increment of $0.01 \mathrm{~mol} / \mathrm{L}$ (in the range of $\mathrm{K}$ concentrations lower than $0.05 \mathrm{~mol} / \mathrm{L}$ ).

Figure 4 shows the leaching ratio of $\mathrm{Sr}$ in leachate with varying $\mathrm{pH}$. The leaching ratio of $\mathrm{Sr}$ was lower than $0.3 \%$ between $\mathrm{pH} 6-12$, which is one order of magnitude lower than that of Cs. The $\mathrm{pH}$ dependence in the leaching of $\mathrm{Sr}$ shows a leaching ratio that decreases with increasing $\mathrm{pH}$, unlike the behavior of Cs. The leaching ratio was less than $0.004 \%$ (and almost no leaching was observed) for all types of leachate at $\mathrm{pH} 8$ and above. Also differing from $\mathrm{Cs}$, there were no recognizable differences in the leaching ratios between different salt types of leaching liquids.

Figure 5 shows the leaching ratios of $\mathrm{Cs}$ and $\mathrm{Sr}$ congeners when $\mathrm{NaOH}$ is used for leaching. There are increases in the leaching ratios with $\mathrm{Cs}$ congeners $\mathrm{K}$ and $\mathrm{Rb}$ and increases in $\mathrm{pH}$, but decreases in leaching ratios with congeners $\mathrm{Mg}$ and $\mathrm{Ca}$ and increases in $\mathrm{pH}$, which is similar

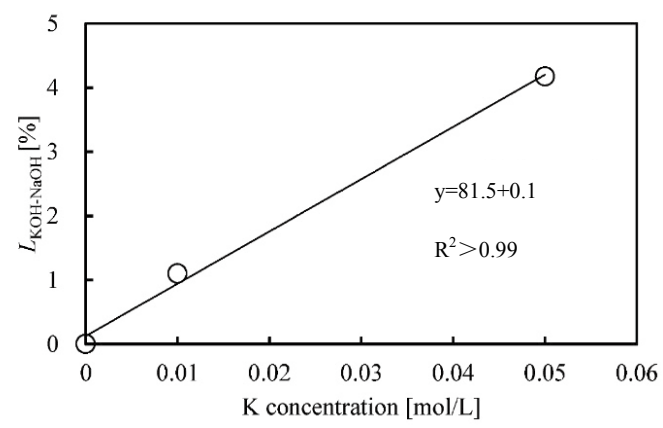

Figure 3 Effect of $\mathrm{K}$ concentration on $L_{\mathrm{KOH}-\mathrm{NaOH}}$ value

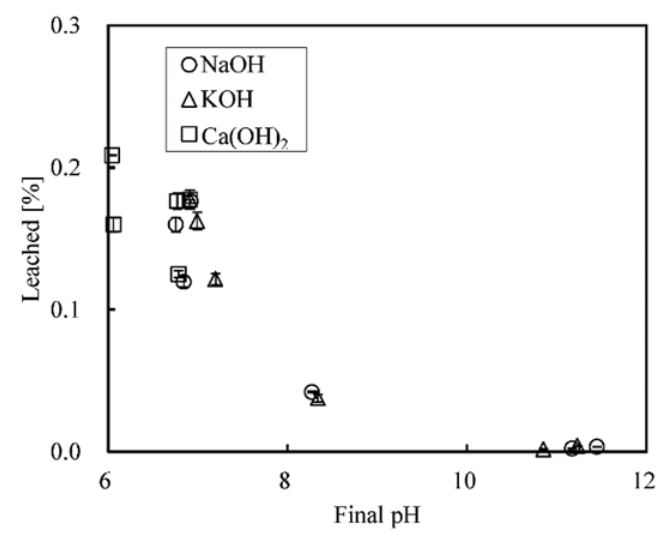

Figure $4 \mathrm{pH}$ dependence of leaching of $\mathrm{Sr}$ ( solid/liquid ratio $=0.1$ ) 
to the behavior or $\mathrm{Sr}$.

$\mathrm{Ca}$ is reported to exist in sewage sludge ash as calcium phosphate $\left(\mathrm{Ca}_{3}\left(\mathrm{PO}_{4}\right)_{2}\right)$ or hydroxyapatite $\left(\mathrm{Ca}_{10}\left(\mathrm{PO}_{4}\right)_{6}(\mathrm{OH})_{2}\right)^{17,18)}$. The solubility products indicate low solubilities of $10^{-26}$ for $\mathrm{Ca}_{3}\left(\mathrm{PO}_{4}\right)_{2}$ and $10^{-108}-10^{-128}$ for $\mathrm{Ca}_{10}\left(\mathrm{PO}_{4}\right)_{6}(\mathrm{OH})_{2}$ and show higher values of still difficult solubilities with increasing $\mathrm{pH}$, with a peak at around $\mathrm{pH} 9{ }^{19}$. $\mathrm{Sr}$ and $\mathrm{Ca}$ show similar behavior, and therefore, $\mathrm{Sr}$ is considered to exist in ash as strontium phosphate $\left(\mathrm{Sr}_{3}\left(\mathrm{PO}_{4}\right)_{2}\right)$, solubility product $10^{-27.4}$. and insoluble under alkaline conditions.

The possibility of Cs existing in sewage sludge ash as an alminosilicate compound (CsAl$\mathrm{Si}_{2} \mathrm{O}_{6}$, etc.) has also been reported ${ }^{11)}$. The leaching ratio of $\mathrm{Al}$ was $0.01 \%$ at $\mathrm{pH} 8.3$, but increased to $14.7 \%$ at $\mathrm{pH} 11.4$ when leached by an $\mathrm{NaOH}$ solution. These results indicate that some of the $\mathrm{Al}$ or $\mathrm{Si}$ within aluminosilicate compounds in the sewage sludge ash was dissolved due to the increased $\mathrm{pH}$, and $\mathrm{Cs}$ was then accordingly leached.

\section{Change in Leaching Ratio and pH in Relation to Solid/Liquid Ratio}

A higher solid/liquid ratio is expected at final disposal sites where precipitation levels are high, as a larger amount of liquid will contact the solid phase over time. To confirm whether the leaching ratio varies with rainfall, we studied the influence of the solid/liquid ratio on the leaching ratio.

The leaching ratios of $\mathrm{Cs}$ and $\mathrm{Sr}$ with respect to the solid/liquid ratio are shown in Figure 6. It is evident that the leaching ratio of Cs decreased with an increase in the solid/liquid ratio, and

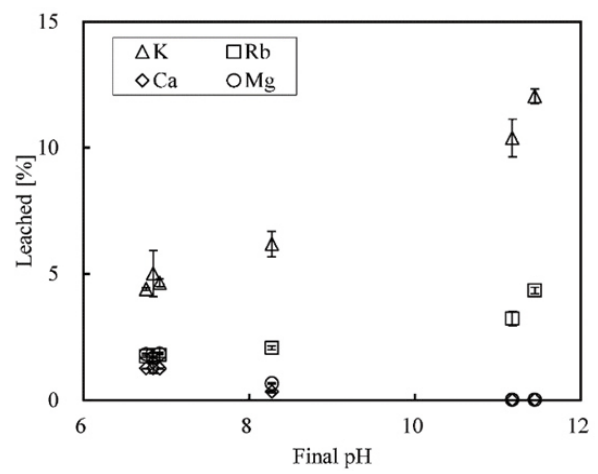

Figure $5 \mathrm{pH}$ dependence of leaching of $\mathrm{K}, \mathrm{Rb}, \mathrm{Ca}$, and $\mathrm{Mg}$ in $\mathrm{NaOH}$ solution

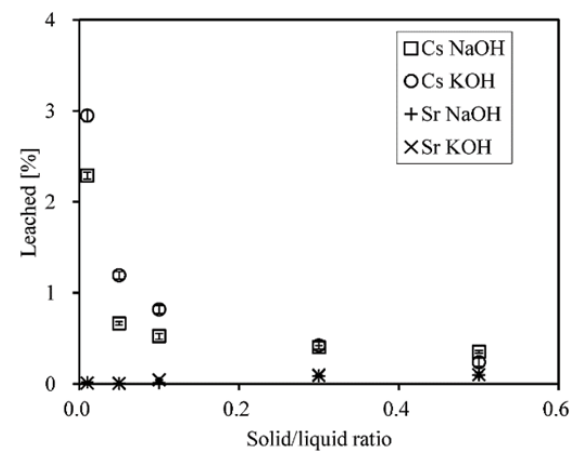

Figure 6 Solid/liquid ratio dependence of leaching of $\mathrm{Cs}$ and $\mathrm{Sr}$ 
the leaching ratio was higher when the solid/liquid ratio was low and when the $\mathrm{KOH}$ solution was used compared to when leaching with the $\mathrm{NaOH}$ solution. However, no differences were seen between the leaching ratios of the two solutions when the solid/liquid ratio was 0.3 and over. The leaching ratio of $\mathrm{Sr}$ differed from that of $\mathrm{Cs}$; although it showed a low leaching rate itself, this amount increased 10 -fold within a solid/liquid ratio range of 0.01 to 0.5 . Furthermore, no difference was observed in leaching ratios when leaching with either $\mathrm{NaOH}$ or $\mathrm{KOH}$ solution.

The $\mathrm{pH}$ decreased with an increase in the solid/liquid ratio; this is considered to be due to the higher $\mathrm{OH}^{-}$consumption with a higher solid phase percentage via the reaction of $\mathrm{Al}^{3+}+$ $4 \mathrm{OH}^{-} \rightarrow\left[\mathrm{Al}(\mathrm{OH})_{4}\right]^{-}$, which occurs when the ash and solution make contact. Additionally, the variation in leaching ratio with various solid/liquid ratios showed a match with the influence of $\mathrm{pH}$ on the leaching ratio for a solid/liquid ratio of 0.1, as shown in Figures 2 and 4, for Cs and $\mathrm{Sr}$ (Figures $\mathbf{7}$ and $\mathbf{8}$ ). Therefore, a study investigating leaching from ash was conducted to separately observe the influences of the solid/liquid ratio and the $\mathrm{pH}$, where the leaching quantity per $1 \mathrm{~L}$ of liquid $\left(L_{1}[\mu \mathrm{g} / \mathrm{L}]\right)$ was first calculated using the Cs leaching ratio $(L[\%])$ when leached at various $\mathrm{NaOH}$ concentrations, and then with a constant solid/liquid ratio of 0.1 . Figures 2 and 4 show the relationship between $\mathrm{pH}$ and the leaching ratio $(L[\%])$ for $\mathrm{Cs}$ and $\mathrm{Sr}$ when leached with the $\mathrm{NaOH}$ solution, and this can be expressed by the following equation as

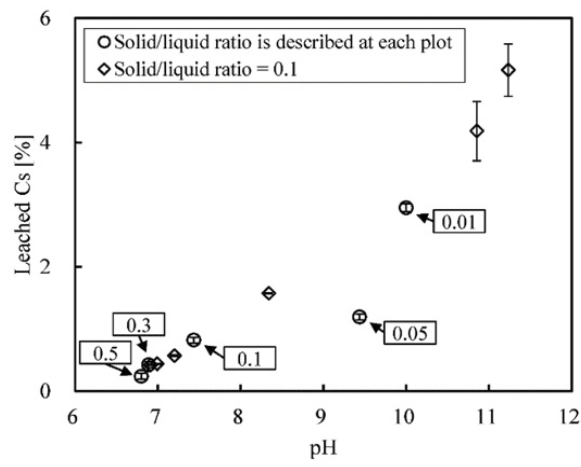

Figure 7 Comparison of leaching of $\mathrm{Cs}$ with $\mathrm{pH}$ at different experimental conditions using $\mathrm{KOH}$ as leaching solution

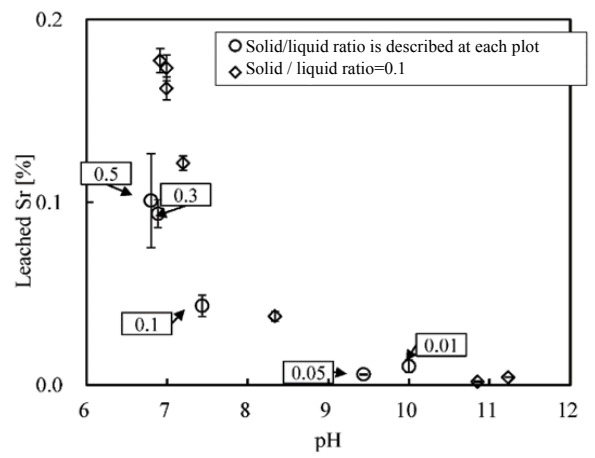

Figure 8 Comparison of leaching of $\mathrm{Sr}$ with $\mathrm{pH}$ at different experimental conditions using $\mathrm{KOH}$ as leaching solution 

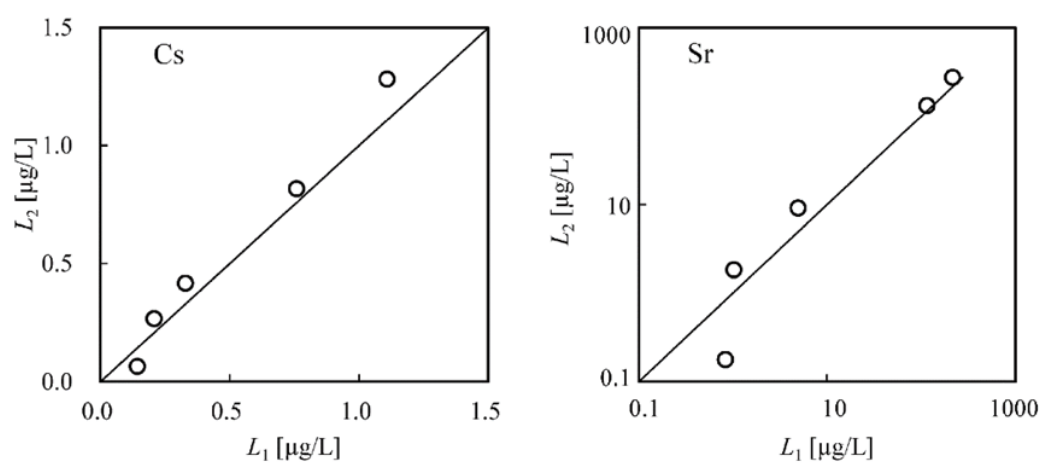

Figure 9 Relationships between $L_{1}$ and $L_{2}$ values

$$
\begin{aligned}
& \text { Cs }: \mathrm{L}=0.076 \mathrm{e}^{0.24 \mathrm{pH}} \quad\left(R^{2}=0.96\right) \\
& \mathrm{Sr}: \mathrm{L}=62.47 \mathrm{e}^{-0.88 \mathrm{pH}} \quad\left(R^{2}=0.98\right)
\end{aligned}
$$

Using the leaching ratio acquired by substituting the equations above with the final $\mathrm{pH}$ at various solid/liquid ratios, the leached quantity $\left(L_{2}[\mu \mathrm{g} / \mathrm{L}]\right)$ per liquid quantity was calculated. The relationship of $L_{1}$ and $L_{2}$ is shown in Figure 9. As the ratios of $L_{1}$ and $L_{2}$ were approximately 1 for both $\mathrm{Cs}$ and $\mathrm{Sr}$, the behavior of leaching from sewage sludge ash can only be explained with respect to the influence of $\mathrm{pH}$. It is thus indicated that $\mathrm{pH}$, rather than the solid/liquid ratio, is the dominant factor in the leaching of $\mathrm{Cs}$ and $\mathrm{Sr}$ from sewage sludge ash.

\section{Quantity Leached from Sewage Sludge Ash in Landfill Site}

Based on this study, the amounts of radioactive $\mathrm{Cs}$ and $\mathrm{Sr}$ leached in leachate, and their concentrations in leachate, were evaluated at a landfill site where sewage sludge ash was deposited. First, the leaching ratio was determined, and the leaching experiment indicated that the leaching ratio of $\mathrm{Cs}$ and $\mathrm{Sr}$ from sewage sludge ash is dependent on $\mathrm{pH}$. In addition to the actual $\mathrm{pH}$ of leachate at landfill sites, which differs greatly between sites, from near $\mathrm{pH} 7^{20)}$ to approximately $\mathrm{pH} 6-8^{14)}$ or $\mathrm{pH} 11.5-11.8^{21)}$, inter-annual variability may have an influence. Accordingly, as an evaluation on the safe side, the highest Cs leaching ratio of $5.2 \%$ (solid/liquid ratio $0.1, \mathrm{KOH} 10^{-1} \mathrm{~mol} / \mathrm{L}$ ) and $\mathrm{Sr}$ leaching ratio of $0.18 \%$ (solid/liquid ratio 0.1 , ultrapure water) were adopted for this calculation.

The upper limit for radioactive Cs in the waste permitted in landfill at existing controlled final disposal sites is $8,000 \mathrm{~Bq} / \mathrm{kg}$. For sewage sludge ash containing radioactive Cs producing $8,000 \mathrm{~Bq} / \mathrm{kg}$, the highest leaching rate $\left(L_{\max }\right)$ in this experiment was $5.2 \%$; therefore, the maximum quantity of leaching radioactive $\mathrm{Cs}$ was $416 \mathrm{~Bq} / \mathrm{kg}$. One study determined that the optimum moisture content $(\mathrm{w}=($ moisture weight $[\mathrm{g}] /$ soil weight $[\mathrm{g}]) \times 100)$ for compacting sewage sludge ash is $58 \%{ }^{22)}$; therefore, the maximum radioactive $C$ s concentration $\left(C_{\max }\right)$ in the leachate water was estimated as $717 \mathrm{~Bq} / \mathrm{L}$ using the equation below

$$
C_{\max }=\frac{8000 \times L_{\max }}{w / 100}
$$

The standard values for radioactive material concentration in landfill effluent are $60 \mathrm{~Bq} / \mathrm{L}$ for ${ }^{134} \mathrm{Cs}$ and $90 \mathrm{~Bq} / \mathrm{L}$ for ${ }^{137} \mathrm{Cs}^{7}$; therefore, our estimated concentration exceeds the effluent standard. Consequently, the possibility of leachate containing a high radioactive Cs concentration 
that exceeds the effluent standard value is indicated if it contains a high concentration of radioactive $\mathrm{Cs}$, even in sewage sludge ash with a low Cs leaching ratio.

Sewage sludge ash is disposed of as landfill as a three-meter-thick swathe that is covered by a soil layer measuring $50 \mathrm{~cm}$ to retain radioactive $\mathrm{Cs}$, or by proper treatment of radioactive Cs and leachate treatment. Using the experimental results and data from existing research, the concentration of radioactive $\mathrm{Cs}$ in the leachate generated from a final disposal site where ash is disposed of as landfill was estimated and studied. Various waste in addition to sewage sludge ash is disposed of at final disposal sites, and therefore leaching from these wastes also needs to be considered. However, data regarding the leaching of ${ }^{133} \mathrm{Cs}$ from other waste, such as cement-type material, has not been reported and is thus difficult to consider. Ishikawa et al. ${ }^{23)}$ made several measurements of ${ }^{133} \mathrm{Cs}$ in leachate at a controlled final disposal site where sewage sludge ash was disposed of as landfill and reported an average of $2.78 \mu \mathrm{g} / \mathrm{L}$, while the concentration of ${ }^{133} \mathrm{Cs}$ leached from sewage sludge ash measured in this research was $3.4 \mu \mathrm{g} / \mathrm{L}$. Furthermore, the concentration of $\mathrm{K}$ (a congener of $\mathrm{Cs}$ that has an adsorbing behavior similar to soil) has been reported as $423 \pm 172 \mu \mathrm{g} / \mathrm{L}^{20)}$ for leachate, while the maximum leaching concentration of $\mathrm{K}$ was $806 \mathrm{mg} / \mathrm{L}$ in the sewage sludge ash acquired in this research. It is considered that the rate of reduction in the Cs or K concentration in leachate occurs when the salt concentration in the leachate is high; the adsorption of Cs or K to soil is low when the leachate infiltrates the soil layer because of competition with other elements present in leachate. The result shows the same order for the leaching concentration, and the concentration in the leachate implies a certain level of reasonability. From the evaluation conducted in this research, ${ }^{133} \mathrm{Cs}$ in leachate is assumed to be derived from sewage sludge ash.

The highest reported ${ }^{133} \mathrm{Cs}$ concentration in sewage sludge ash was approximately $0.85 \mathrm{mg} / \mathrm{kg}^{24)}$, and based on this result, the ratio of ${ }^{133} \mathrm{Cs} /$ radioactive $\mathrm{Cs}$ can be determined to be $0.106 \mathrm{mg} / \mathrm{Bq}$ when sewage sludge ash of $8,000 \mathrm{~Bq} / \mathrm{kg}$ is disposed of as landfill. The maximum concentration of radioactive $\mathrm{Cs}\left(C_{\max }{ }^{\prime}\right)$ in leachate can then be calculated using the formula below,

$$
C_{\max }{ }^{\prime}=\frac{2.78}{0.106}=26.2
$$

$C_{\text {max }}{ }^{\prime}$ was estimated as $26.2 \mathrm{~Bq} / \mathrm{L}$, which does not exceed the effluent standard, and this result indicates that the current prevailing method for retaining radioactive Cs using a soil layer is working.

An increase in the $\mathrm{pH}$ of leachate has been observed in the dry season when there is less rainfall at final disposal sites ${ }^{25}$. The $\mathrm{pH}$ of leachate lowers during heavy rain, and the leaching ratio from ash is thus accordingly lower; therefore, it is not possible for the concentration in the leachate to exceed the level evaluated above.

The effluent standard for radioactive $\mathrm{Sr}$ is not stipulated, but the concentration limit for ${ }^{90} \mathrm{Sr}$ in effluent has been defined as $30 \mathrm{~Bq} / \mathrm{L}$ in an announcement that specifies the dose limits, etc. in accordance with stipulations relating to the installation or operation of nuclear reactors used for experiments and research. With respect to the Fukushima Daiichi Nuclear Power Plant Accident, the ${ }^{90} \mathrm{Sr} /{ }^{137} \mathrm{Cs}$ ratio in contaminated material is estimated as $3 \times 10^{-3}{ }^{26}$ ), and if it is assumed that all of the $8,000 \mathrm{~Bq} / \mathrm{kg}$ of radioactive Cs consists of ${ }^{137} \mathrm{Cs}$, the concentration of ${ }^{90} \mathrm{Sr}$ is thus assumed to be $24 \mathrm{~Bq} / \mathrm{kg}$. The highest leaching ratio of $\mathrm{Sr}$ in this experiment was $0.18 \%$, therefore the leaching rate of radioactive $\mathrm{Sr}$ estimated by this research is $43.2 \mathrm{mBq} / \mathrm{kg}$, and the concentration in the leachate is $74 \mathrm{mBq} / \mathrm{L}$ if the optimum moisture content above is considered. This value is thus lower than the limit concentration in effluent, as explained above. 
This shows that the contribution of ${ }^{90} \mathrm{Sr}$ to the leaching of radioactive materials from the landfill site to the leachate is extremely small (for sewage sludge ash containing radioactive materials), and results indicate that it is only necessary to consider the effects of ${ }^{137} \mathrm{Cs}$.

\section{Summary}

In this research, a series of batch leaching experiments was conducted to determine the leaching properties of $\mathrm{Cs}$ and $\mathrm{Sr}$ from sewage sludge ash. The leaching ratio of $\mathrm{Sr}$ was found to be $0.21-0.004 \%$ with $\mathrm{pH} 6-12$. As with $\mathrm{Ca}$, a higher $\mathrm{pH}$ inhibited sewage sludge ash leaching, and almost no leaching occurred with a $\mathrm{pH}$ of 8 and above. In contrast to $\mathrm{Sr}$, Cs showed an increased leaching ratio with higher $\mathrm{pH}$ : the maximum leaching ratio was $5.16 \%$ with $\mathrm{pH} 11.2$. These results show that it is mainly necessary to consider the leaching of radioactive Cs to prevent excessive radioactive material from escaping in the leachate when sewage sludge ash is disposed of as landfill.

This research was conducted under a JSPS Sciences Research Grant 12014030.

\section{References}

1) Ministry of the Environment, Radionuclide Monitoring Report in Water Environment 2011, available at, http://www.env.go.jp/jishin/monitoring/results_r-pw-h23/1-1.pdf

2) K. Ito, H. Miyahara, T. Ujiie et al., "Practical approach to decontamination of radioactive cesium-contaminated matter in agricultural region by improved wet classification and use of geomaterials," Trans. At. Energy Soc. Jpn. 11, 255-271 (2012). [in Japanese]

3) Ministry of Agriculture, Forestry and Fisheries, Monitoring Results of Strontium in Fisheries Products Conducted by Fisheries Research Agency, available at, http://www.jfa.maff.go.jp/e/inspection/ pdf/131126_strontium.pdf

4) F. Sakamoto, T. Ohnuki, N. Kozai et al., "Determination of local-area distribution and relocation of radioactive cesium in trees from Fukushima daiichi nuclear power plant by autoradiography analysis," Trans. At. Energy Soc. Jpn. 12, 257-266 (2013). [in Japanese]

5) N. K. Ishikawa, A. Ito, T. Umita, "Fate of radiocesium in sewage treatment process released by the nuclear accident at, Fukushima," Chemosphere, 93, 689-694 (2013).

6) Ministry of Economy, Trade and Industry, Immediate Handling of Byproducts from Water and Sewage Treatment etc. that have been Detected as Radioactive Materials, Ministry of Economy, Trade and Industry (2011). Available at http://www.meti.go.jp / press / 2011 / 06 / 20110616006/20110616006-2.pdf. [in Japanese]

7) Ministry of Land, Infrastructure, Transport and Tourism, Report on Radionuclide Concentrations in Sewage Sludge etc., Ministry of Land, Infrastructure, Transport and Tourism (2014). available at, http:// www.mlit.go.jp/mizukokudo/sewerage/crd_sewerage_tk_000168.html. [in Japanese]

8) Ministry of the Environment, Management of Off-site Waste Contaminated with Radioactive Materials Due to the Accident at Fukushima Nuclear Power Stations, Ministry of the Environment (2012). available at, http://www.env.go.jp/en/focus/docs/files/20121128-58.pdf

9) T. Takano, Y. Tamura, Y. Nishizaki et al., "Separation and removal of radiocesium from MSW final disposal site leachate using zeolite," Toshi Seisou, 65, 218-222 (2012). [in Japanese]

10) National Institute for Environmental Studies, Appropriate Waste Disposal Taking into Account Behavior of Radionuclides, National Institute for Environmental Studies (2011). Available at, http://www.env. go.jp/jishin/attach/haikihyouka_kentokai/10-mat_3.pdf. [in Japanese]

11) I. Thushima, M. Ogoshi, "Long term leaching study in sewage sludge contaminated with radioactive materials," J. Jpn. Soc. Water Environ., 50, 108-112 (2013). [in Japanese]

12) S. Urabe, "Treatment of leaching water from landfill disposal of solid wastes," Environ. Conservation Eng., 11, 275-282 (1982). [in Japanese]

13) H. Fukui, T. Yokoyama, "Long-term alteration of water quality in leachate from waste landfills," $J$. Environ. Lab. Assoc., 29, 162-166 (2004). 
14) R.K. Rowe, R. M. Quigley, R. W. I. Brachman, J. R. Booker, Barrier Systems for Waste Disposal Facilities, Second Edition, E\&FN Spon Press, London, 50-62, ISBN 0419226303 (2004).

15) Japan Sewage Works Association, Wastewater Examination Method, vol. 2, Japan Sewage Works Association, Tokyo, 215-216 (1997). [in Japanese]

16) K. Kaikake, T. Sekito, M. Tsunomori, Y. Dote, "Lead stabilization mechanisms of $\mathrm{AlPO}_{4}$ prepared from waste acid etchant in municipal solid waste incineration fly ash," J. Jpn. Soc. Mater. Cycles Waste Manage., 24, 53-62 (2013). [in Japanese]

17) Y. Yoshida, T. Noike, "Influence of temperature on alkaline elution of incinerator ash of sewage sludge," J. Environ. Syst. Eng., 762, 83-90 (2004). [in Japanese]

18) M. Sasaki, Y. Adachi, M. Ika, H. Nishikawa, "Studies on effective use of phosphorus resource obtained from sewage sludge," Rep. Gifu Pref. Res. Inst. Health Environ. Sci., 18, 13-17 (2010). [in Japanese]

19) M. Akiyama, S. Kawasaki, "Fundamental study on new grouting material using calcium phosphate compounds-Crystal precipitation test and unconfined compression test of sand test pieces-," Jpn. Geotech. J., 6, 341-350 (2011). [in Japanese]

20) N. Ishikawa, A. Ito, T. Umita, "Fundamental study about radionuclides removal from landfill leachate," Proc. 50th Environmental engineering research forum, Sapporo, Japan, Nov. 19-21, 2013 (2013).

21) T. Sasajima, K. Kawasaki, Y. Tuchihara, T. Mori, Stabilization of Controlled Landfill of Industrial Waste (X), Bulletin of Toyama Prefectural Environmental Science Research Center, No. 32-2, 32-37 (2004). [in Japanese]

22) M. Kamon, T. Katsumi, T. Inui et al., "Evaluation of geo-environmental impact due to the leachate from solid wastes," Ann. Disas. Prev. Res. Inst., Kyoto Univ., 42 B-2, 459-469 (1999).

23) N. K. Ishikawa, A. Ito, T. Umita, Evaluating Removal of Radionuclides from Landfill Leachate Using Generally Practiced Wastewater Treatment Processes, Radiation Monitoring and Dose Estimation of the Fukushima Nuclear Accident, Springer, Tokyo, 127-134, ISBN 9784431545828 (2014).

24) N. K. Ishikawa, A. Ito, K. Tagami, T. Umita, "Fate of radiocesium in sewage treatment process released by the nuclear accident at Fukushima," Chemosphere, 93, 689-694 (2013).

25) H. Fukui, M. Takahashi, K. Saitoh, H. Sakamoto, Research on the stabilization to judge the abolition of the landfill site, Bulletin of Kanagawa Environmental Research Center, 29, 80-89 (2006). [in Japanese]

26) Ministry of Health, Labour and Welfare, The Philosophy of Contributing Ratio of Radiocesium to Internal Radiation Dose Due by Food Ingestion, Ministry of Health, Labour and Welfare, available at, http:// www.mhlw.go.jp/stf/shingi/2r9852000001w5ek-att/2r9852000001w5je.pdf. [in Japanese] 